\title{
Influence of laser irradiation on the growth and biosynthetic indicators of basidiomycete strains of carotenoid synthesis
}

\author{
Anastasiia Shelest ${ }^{1^{*}}$, \\ Anastasia Velygodska ${ }^{2}$,

\section{Daria Kramarenko ${ }^{3}$} \\ ${ }^{1}$ Vytautas Magnus University, \\ K. Donelaičio St. 58, Kaunas, \\ 44248, Lithuania \\ ${ }^{2}$ Vasyl' Stus Donetsk National University, \\ 600-richya St. 21, Vinnytsia 21021, \\ Ukraine \\ ${ }^{3}$ Bogomolets National Medical University, \\ 13 T. Shevchenko Blvd., Kyiv 01601, \\ Ukraine
}

\begin{abstract}
This article provides information about the ways of increasing the biosynthetic activity of carotenoids by basidiomycetes Laetiporus sulphureus and searching for the most productive strain of L. sulphureus by using various light spectra. We explored the radial growth, biomass increase, and biosynthesis of carotenoids of L.sulphureus. Threestrains of L.sulphureus werescreened:Ls-0917, $L s-0918$, and $L s-0919$. They were isolated from wild plants. Surface cultivation was performed for observing the dynamics of biomass and carotenoid accumulation. The results demonstrated that certain modes of monochromatic irradiation of coherent light could increase radial carotenoid growth, biomass, and biosynthesis in mycelium and culture filtrate. We defined the most productive strains that had the greatest daily growth of mycelium. Furthermore, we discovered that observed cultures could accumulate carotenoids throughout the cultivation period.
\end{abstract}

Keywords: Laetiporus sulphureus, carotenoids, natural pigments, antioxidants, tinder fungus

\section{INTRODUCTION}

One of the most popular biologically active substances is carotenoids. They are natural organic pigments, polyene isoprenoids of the terpene series, which are widespread in wildlife (Yiguang et al., 2018).

It has been revealed that carotenoids can prevent manifestations of atherosclerosis, arthrosis, cataracts, and infections, as well as related diseases of the heart and blood vessels. In addition, they have anticarcinogenic, immunomodulatory, anti-inflammatory, and antioxidant effects (Gammone et al., 2015; Bee et al., 2019).

\footnotetext{
*Corresponding author. Email: anastasiia.shelest@stud.vdu.lt
}

Despite a range of positive effects of carotenoids on the body with a chronic lack of these pigments in the daily diet, a number of pathological processes occur in the body (Moore et al., 2011). That is why the development of biologically active additives, perfumes, and cosmetics containing carotenoids has become such a popular and demanded direction for studies.

In the modern world, an active search for new sources of these biologically active substances is conducted (Torregrosa-Crespo et al., 2018). Nowadays, however, the knowledge of the qualitative and quantitative content of carotenoids in basidiomycetes, their mycelia, and culture filter during their cultivation is insufficient, which necessitates further screening work in this direction (Veligodska, 2012). 
Among medicinal mushrooms, one of the most perspective fungi is the basidiomycete L. sulphureus, a producer of carotenoids (Velygodska et al., 2016). This fungus can be widely used to obtain preparations providing antioxidant protection (Becker, 1988).

Based on this, the aim of this research was to study the ways to increase the biosynthetic activity of the carotenoids of basidiomycetes L. sulphureus by searching for the most productive strain, determining optimal cultivation conditions, and studying the influence of various light emission spectra.

\section{MATERIALS AND METHODS}

Pure culture method. Mushrooms were isolated in pure culture and observed in vitro. The isolation of pure cultures of basidiomycetes was carried out by seeding a sterile piece $(5 \times 5 \mathrm{~mm})$ of vegetative mycelium on culture media.

The presence of pure cultures makes it possible to evaluate the dependence of fungal growth on environmental factors (temperature, light sources) and to describe morphogenetic features.

Determination of growth characteristics. For determination of the linear growth, we measured the diameter of the colony (from the seeding site to the end of the mycelial growth zone) in Petri dishes, at certain intervals. For this aim, the studied fungus was sown in the centre of a dense nutrient medium surface (Becker, 1988). The diameter of the colony was measured in two mutually perpendicular directions at certain intervals of time $(10,15,20$ days). The number of measurements depended on the growth rate of the fungus.

Determination of carotenoid content. For determination of the total carotenoid content, the mycelium was homogenized by grinding in a sterile mortar and extracted with acetone in a 1:10 ratio. The mixture was centrifuged at $2000 \mathrm{~g}$ for $10 \mathrm{~min}$. The number of carotenoids was determined per unit mass ( $\mathrm{g}$ in mycelium) and per unit volume $\left(\mathrm{cm}^{3}\right.$ in the culture filtrate) by the spectrophotometric method and was calculated according to the Wettstein method (1957).

Chlorophyll content was calculated by the formula:

$\mathrm{Ca}(\mathrm{mg} / \mathrm{L})=9.784 \times \mathrm{E} 662-0.990 \times$ E644 (1),

$\mathrm{Cb}(\mathrm{mg} / \mathrm{L})=21.426 \times \mathrm{E} 644-4.650 \times$ E662 (2),

$\mathrm{C}(\mathrm{a}+\mathrm{b})(\mathrm{mg} / \mathrm{L})=5.134 \times \mathrm{E} 662+20.436 \times$

E644 (3),

Carotenoids content was calculated by the formula:

Carotenoids $(\mathrm{mg} / \mathrm{L})=4.695 \times \mathrm{E} 440-0.268$ $\times \mathrm{C}(\mathrm{a}+\mathrm{b})(4)$,

where: E662, E644 and E440 are the results of measuring chlorophyll colour at wavelengths of $662 \mathrm{~nm}, 644 \mathrm{~nm}$, and $440 \mathrm{~nm}$;

$\mathrm{Ca}, \mathrm{Cb}, \mathrm{Ca}+\mathrm{b}$ are, accordingly, chlorophyll content $\mathrm{a}, \mathrm{b}$, and total.

Then, the pigment content in the test material was calculated (Agarwal, Rao, 1998):

$$
A=x=\frac{c \cdot V}{n \cdot 1000}
$$

where: $A$ - the pigment content in the prototype;

$C$ - the pigment concentration found by the Wettstein formula, $\mathrm{mg} / \mathrm{dm}^{3}$;

$V$ - the volume of the extract, $\mathrm{cm}^{3}$;

$n$ - the sample of the prototype, $g$;

1000 - the coefficient for conversion of pigment concentration to $1 \mathrm{~cm}^{3}$.

Studying the effect of various radiation spectra. To study the effect of laser irradiation on the growth and morphological and cultural characteristics of the fungus L. sulphureus, the mycelium of strain Ls-0917 was cultured for seven days in a Potato Glucose Agar in standard Petri dishes (9 $\mathrm{cm}$ in diameter). Subsequently, using a sterile steel tube, $5 \mathrm{~mm}$ diameter mycelial disks were cut from the uterine culture. Before plating on the substrate, they were irradiated with LED lasers (Reshetnyk et al., 2019). Four types of irradiation were used in the study: the control culture grown without irradiation, while three others had a single exposure to laser light for $15 \mathrm{~s}$ (red, blue, and green spectrum). We used the following LED lasers: BRP-3010-5 
with $635 \mathrm{~nm}$ red wavelength radiation, BBP3010-5 with $405 \mathrm{~nm}$ blue wavelength radiation, and BGP-3010-5 with $532 \mathrm{~nm}$ green wavelength radiation (BOB LASER Co., China). The power of each laser was $100 \mathrm{~mW}$. The density of the energy of laser irradiation was calculated by Vakarchuk's formula (Vakarchuk, 2012).

The energy dose of radiation (the energy of light incident on a unit area) was determined as the product of energy density and exposure time. In each variant of the experiment, radiation energy was $77.3 \mathrm{~mJ} / \mathrm{cm}^{2}$. This value was selected according to the results reported in the literature (Poyedinok et al., 2015).Unirradiated mycelium was used in the control culture. Cultivation was carried out at a temperature of $27 \pm 1^{\circ} \mathrm{C}$ until the Petri dish in the thermostat was completely overgrown with mycelium.

To assess the growth of fungal cultures, we studied and analysed the dynamics of the increase in colonial radial growth depending on the time of cultivation.

\section{RESULTS AND DISCUSSION}

The dynamics of biomass and carotenoid accumulation were screened in three strains of basidiomycetes L. sulphureus: Ls-0917, Ls-0918, Ls-0919.

According to the evaluation of the daily growth of mycelium, the best results were dem- onstrated by strain Ls-0919 with its maximum value on day 8 of cultivation. This period also corresponded to the largest daily increase of strain Ls-0917 (Fig. 1).

The maximum growth rate on Potato Glucose Agar (PGA) was observed for the cultivation of strain Ls-0919. Strain Ls-0917 displayed somewhat positive results, which were only $8-10 \%$ lower than the culture of $L s-0919$ (Fig. 1).

As can be seen the maximum accumulation of biomass was observed on day 15 of cultivation for both strains. Furthermore, accumulation stopped by day 20 of cultivation. This is likely due to the depletion of a certain amount of nutritional resources (Fig. 2). This study reveals that cultivated strains demonstrate the same result as the previously studied strainproducer Ls-08 (Velygodska et al., 2012).

The study of carotenoid content illustrates that cultures can accumulate them throughout the cultivation period.

The largest carotenoid content was observed for strain $L s-0917$ on day 15 (Fig. 3).

The study demonstrates that strains are more productive compared to the previously studied strain-producer Ls-08 (Velygodska et al., 2012).

Further research was conducted with strain Ls-0917. The influence of different light spectra on the increase in L. sulphureus radial growth, biomass, and biosynthesis of carotenoids was

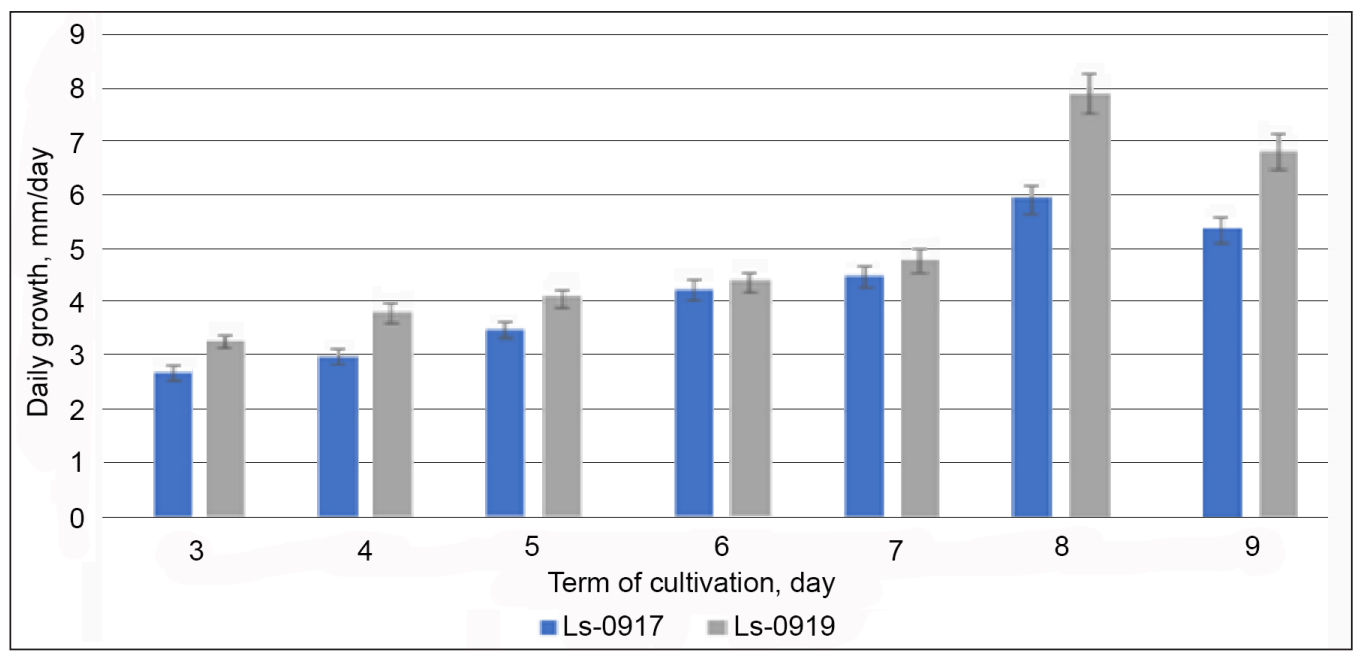

Fig. 1. Daily growth of L. sulphureus strain in PGA 


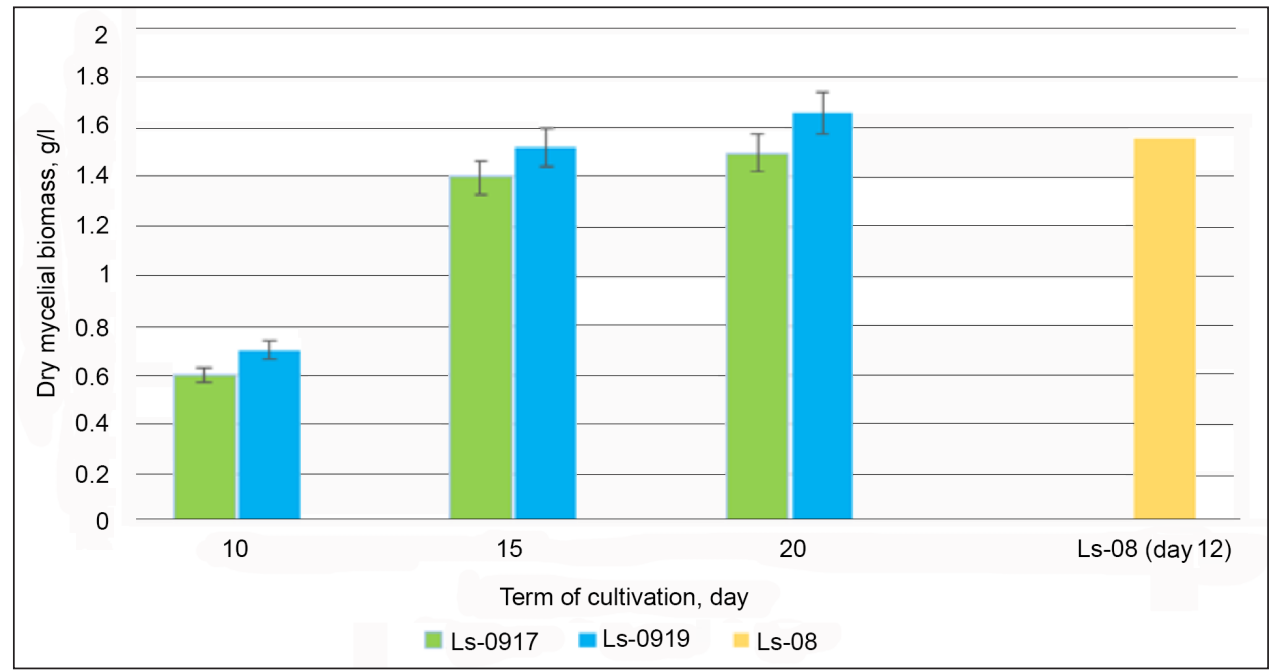

Fig. 2. Accumulated dry mycelial biomass from L. sulphureus in GPM

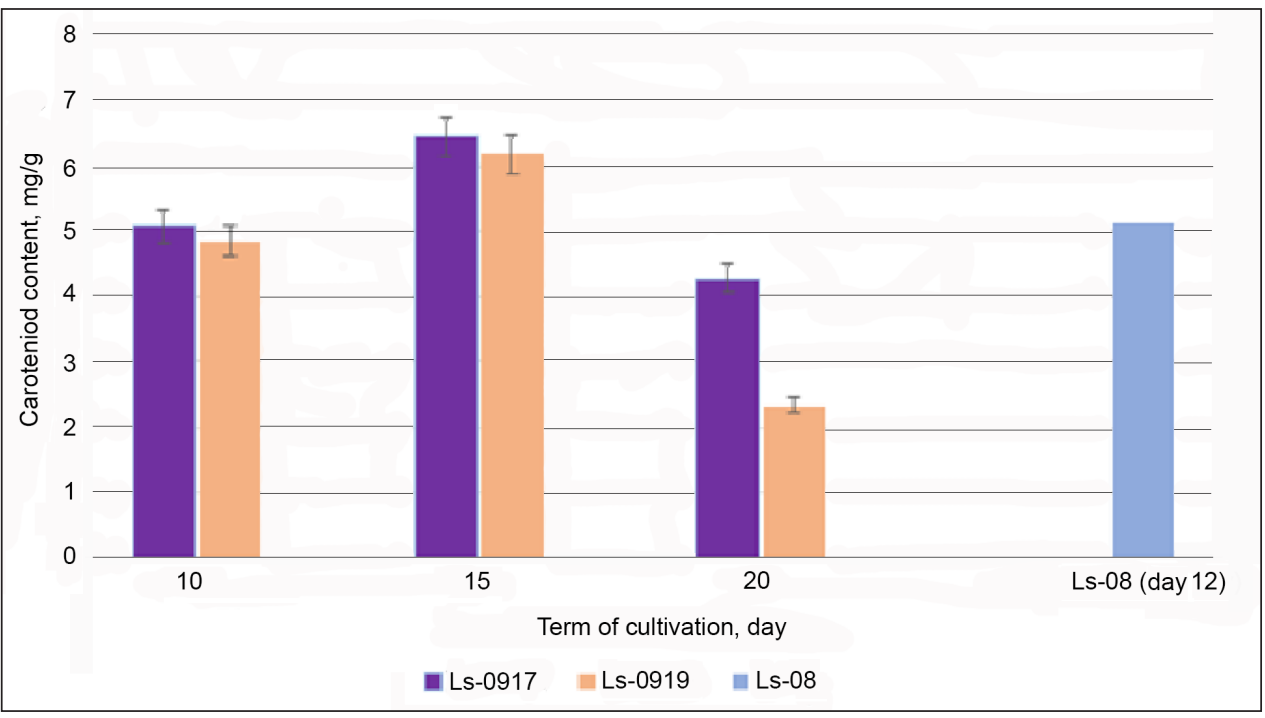

Fig. 3. Dynamics of carotenoid pigment accumulation in mycelium of L. sulphureus strains in GPM

studied using lasers of different light wavelengths, which ensured the generation of coherent light. Three high-power lasers of different light wavelengths were used in the studies: 405 nm (blue spectrum), $532 \mathrm{~nm}$ (green spectrum), and $650 \mathrm{~nm}$ (red spectrum).

According to the evaluation of daily radial growth of mycelium, the best results were illustrated by using red monochromatic light with its maximum value on day 4 of cultivation.

Screening of the results of the increase in absolutely dry biomass, carotenoid accumulation in mycelium and in the culture filtrate was carried out on day 15 of cultivation. The maxi- mum biomass increase was observed on day 15 for strains irradiated with both green and blue monochromatic light.

The strain irradiated with the green spectrum of monochromatic light produced the best result of carotenoid accumulation in the mycelium. The least accumulation was observed in the strain irradiated with red monochromatic light (Fig. 4.).

Based on the data table, the obtained data on the strain L. sulphureus-0917 under the influence of the green irradiation spectrum produced better results in comparison with the previously studied species. 


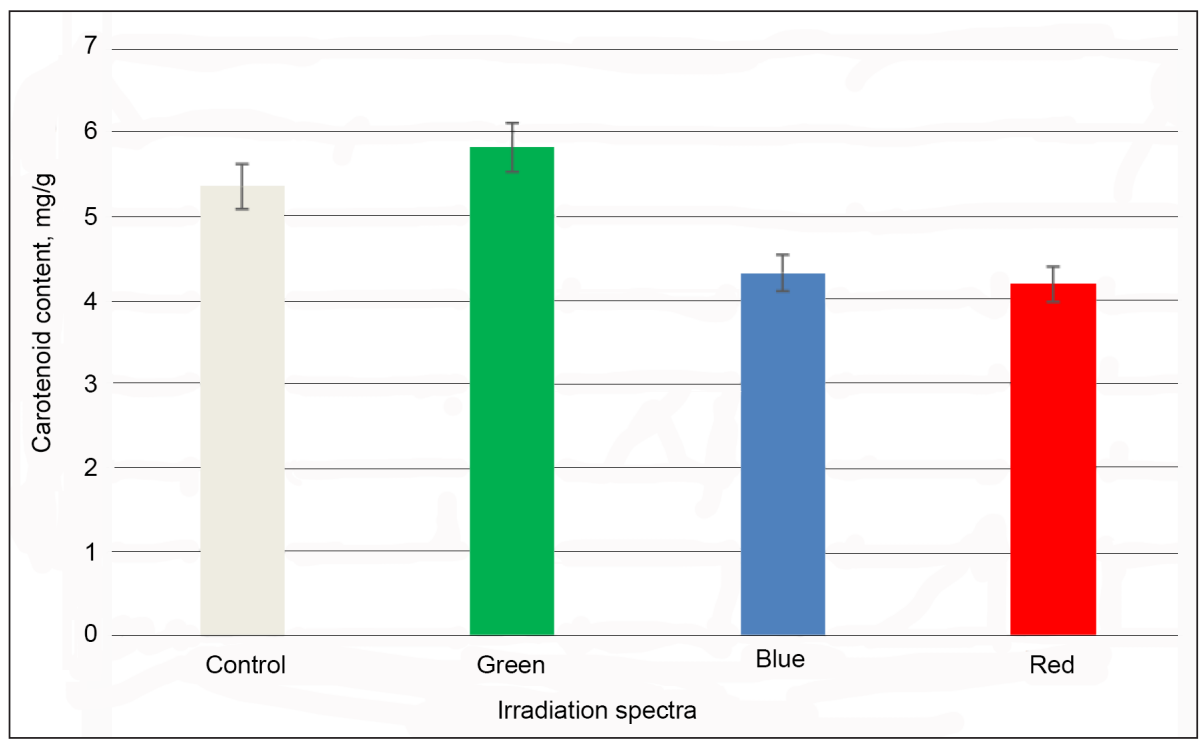

Fig. 4. Dynamics of carotenoid pigment accumulation in the mycelium of L. sulphureus strains on GPM under different irradiation spectra

Scientific novelty of the obtained results is that the carotenoid content in the cultures of basidium fungus strains (L. sulphureus: Ls-0917, $L s$-0918, Ls-0919) was established for the first time. Based on the obtained data, the studied strains are promising producers of carotenoids. The effect of laser irradiation can increase carotenogenesis of L. sulphureus strains.

The practical significance of the obtained results is the identification of most productive strain that could become a source of carotenoids. These strains are more productive compared to the previously studied strain-producer Ls-08 (Ginka et al., 2003; Tinoi et al., 2005; Velygodska et al., 2012).

Despite the wide spread of carotenoids in nature and particularly in fruits, vegetables, and algae, the use of the fungus $L$. sulphureus has several advantages:

- the medicinal fungus L. sulphureus is widely distributed worldwide (Qiang Li et al., 2018);

- these fungi usually have low nutritional requirements during their growth and cultivation, which reduces production costs;

- the maximum carotenoid content is produced as early as day 15;

- production of carotenoids from fungus presents no problems, unlike the plants with seasonal and geographic variability that cannot be regulated (Chang ST et al., 2004).

\section{CONCLUSIONS}

The study proves the possibility of a positive irradiation effect of certain spectra of monochromatic light on the carotenoid synthesis in the mycelium of the investigated strains. L. sulphureus could be used in pharmacy, cosmetics, and production of dietary supplements that need carotenoid content. Consequently, L. sulfureus strains are reliable microorganisms to produce carotenoids.

Received 2 March 2020 Accepted 28 April 2020

\section{References}

1. Agarwal S, Rao AV. Tomato lycopene and low density lipoprotein oxidation: a human dietary intervention study. Lipids. 1998; 33(10): 981-4.

2. Becker ZE. Physiology and biochemistry of mushrooms. Moscow: Publishing House; 1988. 
3. Tan BL, Norhaizan ME. Carotenoids: how effective are they to prevent age-related diseases? Molecules. 2019; 24(9): 1801.

4. Chang ST, Miles PhG. Mushrooms. Cultivation, nutritional value, medicinal effect and environmental impact. London, N. Y., Washington: CRC Press; 2004.

5. Counsell JN. Some synthetic carotenoids as food colours. In: Developments in food colours. London: Applied Science; 1980.

6. Gammone MA, Riccioni G, D’Orazio N. Carotenoids: potential allies of cardiovascular health? Food Nutr Res. 2015; 59: 26762.

7. Frengova GI, Emilina SD, Beshkova DM. Carotenoid production by lactoso-negative yeasts co-cultivated with lactic acid bacteria in whey ultrafiltrate. Zeitschrift für Naturforschung. C, 2003; 562-7.

8. Reshetnyk K, Prysedsky Y, Yuskov D. The influence of laser irradiation on the development of vegetative mycelium Pleurotus ostreatus. Biologija. 2019; 65(4): 243-50. Ukrainian.

9. Moore D, Robson GD, Trinci APJ. 21st Century guidebook to fungi. Cambridge: Cambridge University Press; 2011. 236 p.

10. Poyedinok NL, Myhaylova OB, Hodakovskyy VM, Dudka IA. Influence on growth activity of the seed material of cultivated macromycetes of low-intensity laser radiation. Microbiology and Biotechnology. 2015; 29(1): 77-86. Ukrainian.

11. Tinoi J, Rakariyatham N, Deming RL. Simplex optimization of carotenoid production by Rhodotorula glutinis using hydrolyzed mung bean waste flour as substrate. Process Biochem. 2005; 40: 2551-7.

12. Torregrosa-Crespo J, Montero Z, Fuentes JL, Reig García-Galbis M, Garbayo I, Vílchez C, Martínez-Espinosa RM. Exploring the valuable carotenoids for the large-scale production by marine microorganisms. Mar Drugs. 2018; 16(6): E203.

13. Vakarchuk IO. Quantum mechanics: a textbook. Lviv: Ivan Franko LNU; 2012. 872 p. Ukrainian.

14. Veligodska AK, Fedotov AV. A comparative characteristic of the total carotenoid content in some types of basidiomycetes. Microbiology and biotechnology. 2012; 4(20): 84-96. Ukrainian.

15. Veligodska AK, Fedotov OV. The production and analysis of carotenoid preparations from some strains of xylotrophic basidiomycetes. Visn. Dnipropetr. Univ. Ser Biol Ekol. 2016; 24(2): 290-4. Ukrainian.

16. Wettstein D. Chlorophyll-letale und der submikroskopishe Formweschsel der Plastiden. Exp Cell Res. 1957; 12(3): 427-506. German.

17. Li Q, Yang M, Chen C, Xiong C, Jin X, Pu Z, Huang W. Characterization and phylogenetic analysis of the complete mitochondrial genome of the medicinal fungus Laetiporus sulphureus. Sci Rep. 2018; 8: 9104.

18. Wang Y, Zhang C, Dong B, Fu J, Hu S, Zhao H. Carotenoid accumulation and its contribution to flower coloration of Osmanthus fragrans. Front Plant Sci. 2018; 9: 1499. 


\section{Anastasiia Shelest, Anastasia Velygodska, Daria Kramarenko \\ LAZERIO IRADIACIJOS İTAKA KAROTENA SINTETINANČIŲ BAZIDIOMICETŲ PA- DERMIŲ AUGIMUI IR BIOSINTETINIAMS RODIKLIAMS}

\section{Santrauka}

Straipsnyje pateikiama informacija apie bazidiomicetų Laetiporus sulphureus padidejusį karotenoidų biosintetini aktyvumą ir produktyviausios L. sulphureus padermès paiešką naudojant ịvairius šviesos spektrus. Mes ištyrème L. sulphureus karotinoidų radialụjj augimą, biomasès padidejjimą ir biosintezę. Ištirtos trys iš laukinių augalų išskirtos L. sulphureus padermès: Ls-0917, Ls-0918, Ls-0919. Siekiant stebèti biomasès ir karotenoidų kaupimosi dinamiką, buvo įdirbtas paviršius. Rezultatai rodo, kad tam tikri koherentinès šviesos monochromatinio švitinimo būdai gali padidinti karotenoidų radialụjị augimą, biomasę ir kultūros filtrato biosintezę. Nustatyta, kad stebimos kultūros gali kaupti karotenoidus per visą auginimo laikotarpị. Apibrežème produktyviausias padermes, kurios kasdien labiausiai augino grybieną.

Raktažodžiai: Laetiporus sulphureus, karotenoidai, natūralūs pigmentai, antioksidantai, tikroji pintis 